\title{
EFFECTS OF DRIED LEAF POWDER OF OCIMUM SANCTUM IN HEXAMITA-INFECTED FISH ANABAS TESTUDINEUS
}

\section{PRADIP MONDAL, NIMAI CHANDRA SAHA*}

Department of Zoology, University of Burdwan, Burdwan, 713104, India. Email: sahanvcbu@gmail.com

Received: 26 January 2019, Revised and Accepted: 26 February 2019

\begin{abstract}
Objective: The prophylactic and antioxidative role of the dried powdered of Ocimum sanctum (Tulasi) was measured in Hexamita-infected fish Anabas testudineus.

Method: Four groups of infected fish were kept in four separate aquariums and the following doses of leaf powder applied (25 mg, 50 mg, and $100 \mathrm{mg} / \mathrm{L}$ ) for 10 days, and the first group is considered as control and no such treatment is given there.

Results: Histopathology showed a remarkable alteration in the structure of liver tissue. Progressive changes observe along with the treatment schedule in hepatic histology and differential count of blood. Results showed that Hexamita infections significantly increased (p<0.05) the oxidative stress in the liver of infected fish. Whereas the treated fish exposed to different doses of powdered leaf of 0 . sanctum show significantly higher levels of antioxidant enzymes (Catalase, Superoxide dismutase, Glutathione peroxidase) and lower levels of stress marker (Malondialdehyde) than control fish. This treatment caused a rapid skin formation in the scar region. The highest recovery found in $100 \mathrm{mg} / \mathrm{L} \mathrm{doses} \mathrm{of} \mathrm{leaf} \mathrm{powder,} \mathrm{whereas} \mathrm{the} \mathrm{least}$ recovery found in $25 \mathrm{mg} / \mathrm{L}$ group.
\end{abstract}

Conclusion: The findings of the present study may play a key role in aquaculture industry for controlling the death of fish from Hexamita infection.

Keywords: Aquaculture, Hexamita, Histopathology, Ocimum sanctum, Oxidative stress.

(C) 2019 The Authors. Published by Innovare Academic Sciences Pvt Ltd. This is an open access article under the CC BY license (http://creativecommons. org/licenses/by/4. 0/) DOI: http://dx.doi.org/10.22159/ajpcr.2019.v12i4.31754

\section{INTRODUCTION}

The Holy Basil or Ocimum sanctum is a household medicinal plant commonly known as Tulasi, well known for its remarkable action against a wide range of diseases [1]. Activity includes immunomodulatory, antioxidant activity, antibiotic nature, anti-inflammatory, antiulcer, antipyretic, and chemopreventive properties proven by various researches [2-4]. The immunomodulatory effects of 0 . sanctum have been reported for various animal species [5]. Among a variety of medicinal plant is predominant throughout the world, but 0 . sanctum holds the designation "queen of the herb" and retained since generation after generation due to the enumerable medicinal value [6]. From ancient time, Indian tradition recommended to plant a Tulasi sapling in each house and it is considered as a natural energizer. Researcher has been identified and purifies various components from this plant and characterizes different biopharmacological and chemical substances. Various reports are available by scientists from the different continents, and from India, since the past few decades to prove the essential versatile beneficial role of this medicinal herb for the humankind as well as benefits of the animals [3].

The most common and dangerous cause of fish disease in fish culture than any other fish parasites is protozoan parasites [7,8]. Some parasites like ciliates are obligatory in nature and utilize skin as a substrate for adherence and cause enormous damage. It becomes fatal on small fish when infections occur in moderate levels because these parasites infection may stop feeding of fish [8]. Hexamita sp. is one of the most common protozoan parasite has been associated with medium to severe mortalities in hatcheries $[9,10]$. The mode of infection of the organism is still not clearly understood. Reports show that massive numbers of these protozoa cause high mortalities in fish farm fingerlings and it is not always depends on environmental stress factors [11,12]. This flagellate protozoa is generally an intestinal commensal and it becomes pathogenic only when the number of parasites becomes large in number tropical and temperate fish [13]. Reports suggested that flagellate parasites create problems with the nutrition by consuming essential nutrients by disintegrating the epithelium of intestine [14]. Hexamitiasis is one of the most frequent parasitic infections of fish, specifically in juvenile carp and also some aquarium and many marine fish. Infected fish become weak, restless, and anorexic. Head appears large in respect to the body when the infection becomes in great amount. Fish showing loss of balance in highly infected conditions and they swim on each of either side $[7,15]$. Fish with acute Hexamita infection exhibit higher mortality rate over a very short period of time due to rapid growth of the parasite causes damage to the epithelium. During spring and autumn the chronic form of hexamitiasis generally occurs, resulting higher death rate than noninfected fish [15]. In temperate fish when infection occurred with Hexamita sp. resulting anemia, weight loss, dark body color, intestinal anomaly, excessive mucus secretion, and yellow color mucus secreted from intestine due to addition of bile; in addition, blood also oozing out from infected intestine forms intestinal hemorrhage and hepatic disintegration may also be found $[16,13]$. Fish with heavily infected condition parasites are profound in the digestive tract, did not show any symptoms of damage to mucosa and without invasion of the parasite into the epithelial tissue [17]. Severe infection by this parasite in fish creates the oxidative stress [18]. However, there is no such information available on fish in this context. Nowadays, the practice has profound to replace the commercially available pharmacy chemical by organic substances which is less toxic and environment friendly. O. sanctum is the most common medicinal and easily available widely used medicinal plant to control different infection.

This study is trying to find out the prophylactic quality of dried leaf powdered of $O$. sanctum and its antioxidative role and recovery. This may be used as a curing measure to defend Hexamita infection and reduce mortality of cultured fish without causing any side effect and environmental problems. 


\section{METHODS}

\section{Chemicals}

All chemicals of the highest commercially purity were purchased from Sigma-Aldrich Chemical Co., St. Louis, MO, USA.

\section{Animals}

Adult Anabas testudineus L. $(36 \pm 2.20 \mathrm{~g}$ body weight, $10.1 \pm 1.31 \mathrm{~cm}$ total length) of same group fish were collected from a local farm and were acclimatized to for 4 weeks in tap water in large cemented tank. During this period, they got severely infected by the flagellated protozoa Hexamita. The scars on their head become very prominent and can be easily visible (Fig. 1). They were fed ad libitum. Care taken in the laboratory for fish and adopted protocols for the study followed as per international standards [19].

\section{Experimental paradigm}

The experiment was designed in four glass aquaria with tap water. The values of the different physicochemical parameters of water used in the study were as follows: Having temperature $24 \pm 3.5^{\circ} \mathrm{C}, \mathrm{pH} 7.0 \pm 0.4$, free $\mathrm{CO}_{2} 23.8 \pm 3.2 \mathrm{mg} / \mathrm{l}$, dissolved oxygen $5.1 \pm 0.6 \mathrm{mg} / \mathrm{l}$, total alkalinity $122 \pm 14.23 \mathrm{mg} / \mathrm{l}$ as $\mathrm{CaCO}_{3}$, and hardness $135 \pm 2.25 \mathrm{mg} / \mathrm{l}$ as $\mathrm{CaCO}_{3}$. The fishes were not fed for $24 \mathrm{~h}$ before the commencement of test. Identical groups of 10 infected fish were kept in four separate aquaria containing $6 \mathrm{~L}$ of plain tap water as control (diseased), experimental Group 1 (25 mg/l of 0 . sanctum leaf powder), experimental Group $2(50 \mathrm{mg} / \mathrm{l}$ of $O$. sanctum leaf powder), and experiment $3(100 \mathrm{mg} / \mathrm{l}$ of $O$. sanctum leaf powder). This set of experiment incubated for 10 days in the presence of aerations; then, all the water were changed by fresh tap water. Physical observation recorded (Fig. 2). After 10 days, liver sample was collected by sacrificing the fish and performed biochemical estimations of stress parameter and antioxidant activity.

\section{Histopathology of liver tissue}

For histology, study samples were collected from the liver from each fish and fixed in $10 \%$ neutral formalin. Tissue specimens were processed by routine microtomy of paraffin sections about $4-5 \mu$ m thickness, stained with hematoxylin and eosin [20].

\section{Differential count of blood}

The blood was collected by heparinized syringe from caudal vein puncture and used for the estimation of red blood cells (RBCs) or erythrocyte and white blood cells (WBCs) or leukocytes counts. Erythrocyte and leukocytes were counted using hemocytometer [21].

\section{Enzymatic antioxidative agents}

\section{Superoxide dismutase (SOD) activity}

The activity of SOD was assayed by photochemical inhibition of NBT at $560 \mathrm{~nm}$ [22]. Prepare $10 \%$ liver homogenate in a cold homogenization buffer solution. Centrifuge the suspension at $14,000 \mathrm{rpm}$ for $30 \mathrm{~min}$ at $4^{\circ} \mathrm{C}$ and collect the clear supernatant for the enzyme assay. $100 \mu \mathrm{l}$ of the extract is taken for analyses. Blank is placed in a covered dark stand for limiting the light. Then, they are transferred to an ordinary stand, illuminated with luminescent lamps for $10 \mathrm{~min}$. The absorbance at $560 \mathrm{~nm}$ is read against blank. One unit of SOD activity is defined as that amount of protein (in $\mathrm{mg}$ ) causing a $50 \%$ inhibition of the photoreduction.

\section{Catalase (CAT) activity}

The activity of CAT in the liver supernatants was estimated by the spectrophotometric method [23]. $40 \mu \mathrm{L}$ of the liver supernatant was rapidly mixed with $\mathrm{H}_{2} \mathrm{O}_{2}$ phosphate buffer in a cuvette. Absorbance was measured at $240 \mathrm{~nm}$ using Beckman Coulter, DU 730, Life Science ultraviolet-visible spectrophotometer up to $90 \mathrm{~s}$ at 15 -s intervals.

\section{Glutathione peroxidase (GPx) activity}

GPx activity was determined using spectrophotometric method of Castro et al. [24]. Serial dilutions of the substrate Orthophenyl diphosphate (OPD) of GPx were used in this assay. $1 \mathrm{~mL}$ of each OPD serial dilutions in phosphate-citrate buffer ( $\mathrm{pH}$ 5.0) was mixed with $100 \mu \mathrm{L}$ sample, and then, $0.9 \mathrm{~mL} 0.013 \% \mathrm{H}_{2} \mathrm{O}_{2}$ was added and incubated for $1 / 2 \mathrm{~h}$ at room temperature. Optical density (OD) values were taken at $492 \mathrm{~nm}$ against blank. One unit of enzyme action produced an increasing in absorbance of 1.0 under the assay conditions.

\section{Determination of the level of malondialdehyde (MDA)}

The homogenates of liver were centrifuged for $15 \mathrm{~min}$ at $3000 \mathrm{~g}$ and the supernatants were collected to estimate the level of MDA by thiobarbituric acid (TBA) reactive assay [25]. The process followed by heating of samples $(1 \mathrm{~mL})$ with TBA reagent (20\% trichloroacetic acid, $0.5 \% \mathrm{TBA}$, and $2.5 \mathrm{~N} \mathrm{HCl} ; 2 \mathrm{~mL}$ ) for $20 \mathrm{~min}$ in a water bath at $100^{\circ} \mathrm{C}$. After cooling, the reaction mixture was centrifuged for $10 \mathrm{~min}$ at $500 \mathrm{~g}$ and the supernatant was collected. The OD value was taken at $532 \mathrm{~nm}$. Using an extinction coefficient of $1.56 \times 10^{5} / \mathrm{Mcm}$, the MDA equivalents were calculated.

\section{Statistics}

The data on each studied variable at a particular sampling time were expressed as mean \pm standard error of mean of the individuals $(n=10)$. As all data set are tested by one-way ANOVA. Where F values indicated significance, the means were compared by a post hoc Duncan's multiple range tests (DMRTs), with $\mathrm{p}<0.05$ taken as the statistically significant threshold.

\section{RESULTS}

\section{Physical observations}

After 10 days of treatment with different doses of dried leaf powder, we found a great reduction of the scar area and new skin become reformed. Highest recovery found in $100 \mathrm{mg} / \mathrm{l}$ group, whereas minimum recovery found in $25 \mathrm{mg} / \mathrm{l}$ group in compare to control-infected fish. The fish restore their healthy movement and balance (Fig. 1).

\section{Histopathological observation of liver}

The histopathological examination of all liver collected from fish exposed to different doses of dried leaf powder showed a variation in histological structure. However, the most affected pathological lesions found in control-infected group of fish and gradual improvement in the histopathology were observed from next experimental groups nadir in

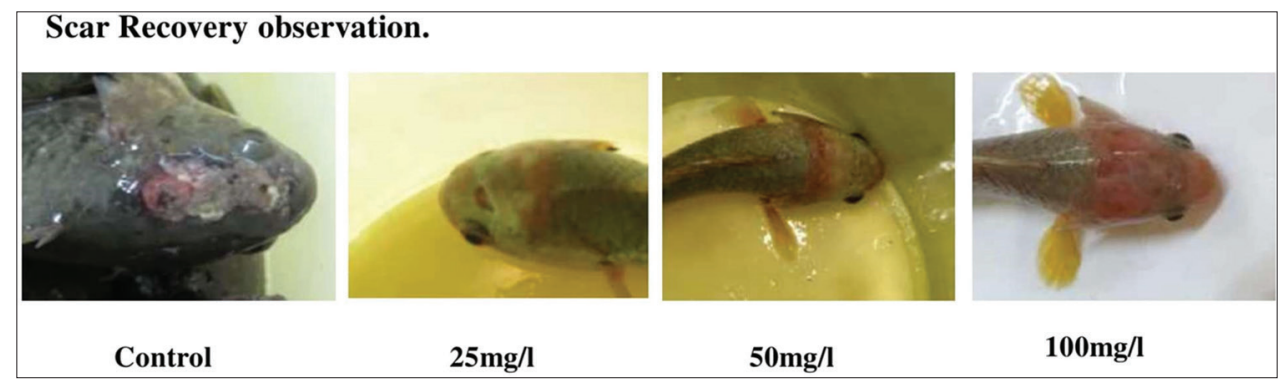

Fig. 1: Different doses of treatment showing various levels of scar recovery in Hexamita-infected fish Anabas testudineus. Highest head scar recovery found in $100 \mathrm{mg} / \mathrm{l}$ group 


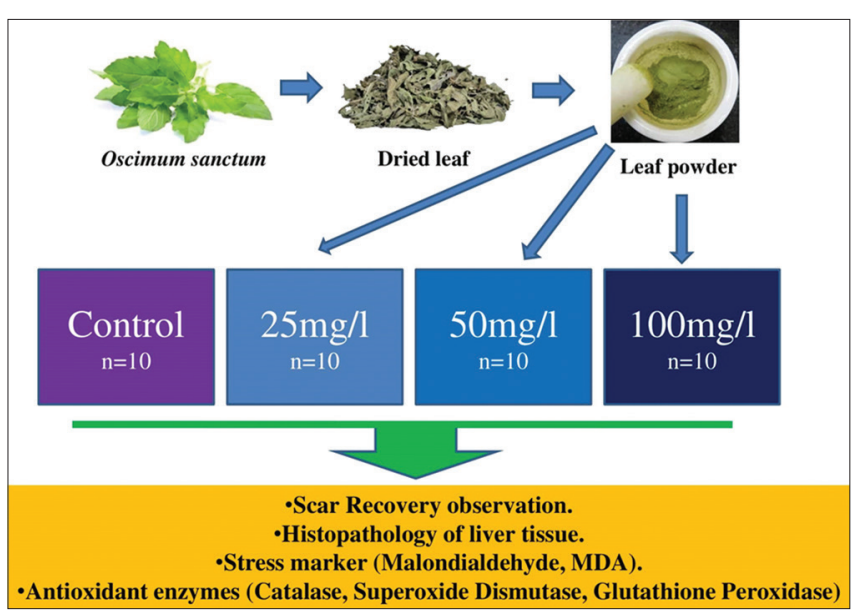

Fig. 2: Graphical representation of experimental paradigm
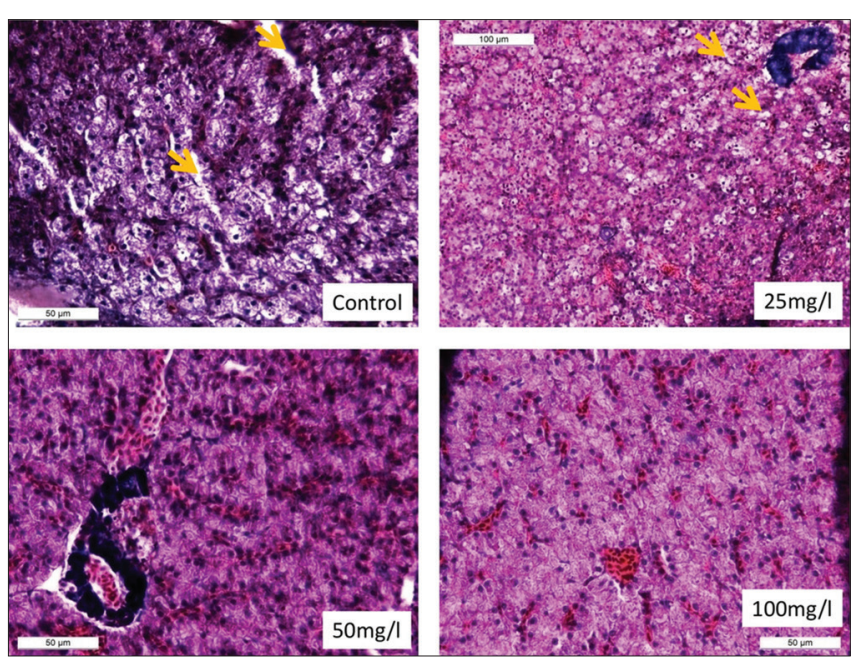

Fig. 3: Photomicrograph of liver tissue showing control (upper left) diseased showing highly damaged condition like big space present between hepatic tissue and pancreas tissue and also hepatopancreas showing vacuolation, $25 \mathrm{mg} / \mathrm{l}$ treated demonstrated slight recovery in tissue structure but some vacuolation also present, $50 \mathrm{mg} / \mathrm{l}$ showing more advancement, and $100 \mathrm{mg} / \mathrm{l}$ showing highest recovery liver of Anabas testudineus. Pancreas is deep blue stained, vacuolation marked by yellow arrow, blood congestion (within the hepatopancreas in image). Stain with $\mathrm{H}$ and $\mathrm{E}$

$25 \mathrm{mg} / \mathrm{l}$ and highest recovery in $100 \mathrm{mg} / \mathrm{l}$. The liver showed vacuolar degeneration of the hepatocytes and disorganization of hepatopancreas in the control group (infected). Gradual vacuolation recovery of hepatocyte structure and hepatopancreas was found on the latter group, respectively (Fig. 3).

\section{Differential blood count}

There is significant difference $(p<0.05)$ in the cell count among different experimental groups. RBCs showing less count in diseased group, whereas its highest count observed in $100 \mathrm{mg} / \mathrm{l}$ group and different treatment groups show gradual increase in cell count. Similar patterns are followed in different WBC count showing least in disease control group, and gradual increasing order followed in different experimental group from 1 to 3 (Fig. 4).

\section{MDA level in liver}

MDA levels in the liver of all groups of treated, control, and diseased fish exhibited significant $(\mathrm{p}<0.001)$ decrease with increasing doses of O. sanctum dried leaf powder with the highest value observed in control (diseased) and gradually decrease in experimental group and nadir value found in $100 \mathrm{mg} / \mathrm{l}$ treatment group (Fig. 5).

\section{Activity of antioxidative enzymes in the liver}

The hepatic activity of SOD, CAT, and GPx exhibited gradual but significant $(\mathrm{p}<0.05)$ increase from control to $100 \mathrm{mg} / \mathrm{l}$ treatment group through increasing doses of 0 . sanctum dried leaf powder. Lowest value found in diseased group and the highest value observed in $100 \mathrm{mg} / \mathrm{l}$ group (Fig. 5).

\section{DISCUSSION}

The present study provides an efficient evidence for 0 . sanctum dried leaf powder having recovery capacity on the head region of the tropical fish A. testudineus in the infection of Hexamita sp. After 10 days of treatment, the scar region becomes fully covered by new skin in infected fish. Hexamita was more important for the mortalities in hatcheries of Salmon, whereas other pathogens were not responsible for this species [17]. Before this experiment, such reports are insufficient for rapid recovery of Hexamita infection in this species or any other fish species by any organic herb. Leaf powder has the capacity to cure this protozoan infection, but it takes longer duration relative to pharmacy chemicals. On the other hand, the use of organic substances reduces the bioaccumulation and ultimately decreases environmental toxic effect. Higher concentration like $100 \mathrm{mg} / \mathrm{l}$ has a better recovery rate. This may help in reduced mortality in fish farm or in stocking of fish. The previous work demonstrated that the treatment for Hexamita using furazolidone cleared the parasites and mortality stopped in 7 days [17].

The differential blood cell count among different experimental groups shows variation on RBC and WBC number. RBCs showing less count in diseased (control) group, whereas its highest count observed in $100 \mathrm{mg} / \mathrm{l}$ group and different treatment groups show gradual increase in cell count. It may be due to heavy infection of Hexamita sp. causes deficiency in nutrition which resulted in less RBC count in diseased fish [14]. There is a possible explanation for this difference in blood cell number may be due to $O$. sanctum leaf powder has stimulatory effect on proliferation of different blood cells. Same incidence found in WBC. Increase in WBC gives an indication about immune-stimulation which may help the fish to maintain body homeostasis. Further, research is needed to prove this hypothesis.

Hexamita is a common commensal parasite and inhabiting within the gastrointestinal tract of fish. When its number becomes amplified, it creates problems to its host. It might not cause severe intestinal changes; attention was focused on the hepatocellular alteration as an alternative explanation for the mortalities [10,26,27]. Unlike histomoniasis of poultry, where the protozoa can invade the circulation from the intestine and cause hepatic necrosis, no evidence for the presence of Hexamita in the liver was found in fish. Our finding is also similar to this and we do not have identified any parasite within the liver. Although this is not conclusive evidence that hepatic necrosis may not be associated with Hexamita infection in carp rather by diet [28]. Our experiment shows that high levels of lipid peroxidation products MDA present in the liver of diseased (Infected) fish, which may demonstrate that individual having high level of oxidative stress due to Hexamita infection. Increased reactive oxygen species in tissues during toxic conditions lead to the oxidation damage to lipids, proteins, and the genome [29]. Parasites have been shown to induce oxidative stress in host-parasite systems. An increased enzyme antioxidant response was observed in carp Cyprinus carpio parasitized by the cestode Ptychobothrium sp. [30] compared to healthy fish, indicating that some components of the fish antioxidant system can be modulated. The previous work demonstrated that an increased tert-butyl hydroperoxide-initiated chemiluminescence, a measure of lipid peroxidation, in the muscle of fish infected with metacercariae of the trematode Clinostomum detruncatum. Gastrointestinal nematodes of mammals rely on proteinases and oxidative damage for tissue penetration and nutrients [30]. Similar 


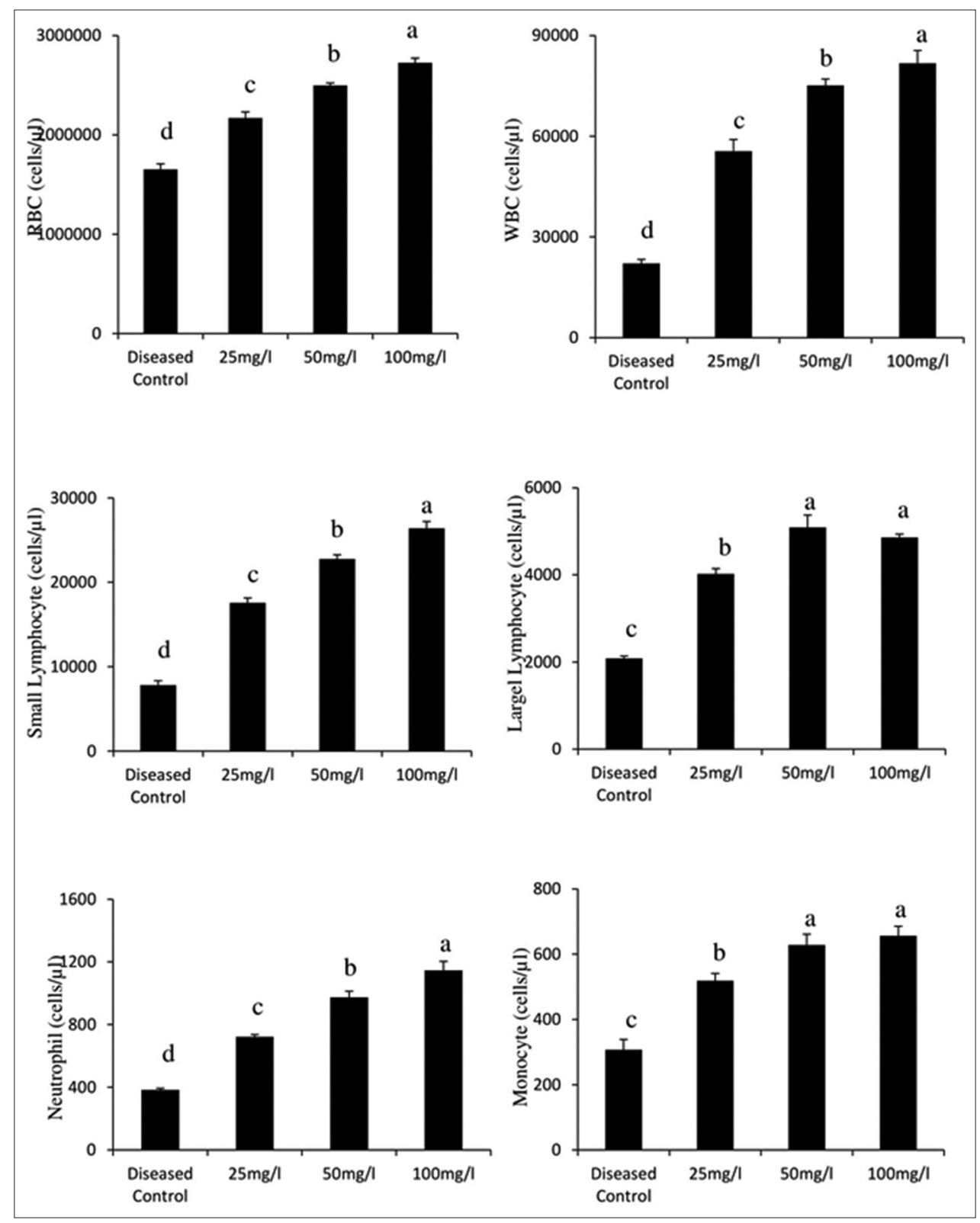

Fig. 4: Histogram showing the mean values ( \pm standard error of mean, in vertical bars) of the differential count in blood cells of Anabas testudineus in different experimental group following control, $25 \mathrm{mg} / \mathrm{l}, 50 \mathrm{mg} / \mathrm{l}$, and $100 \mathrm{mg} / \mathrm{l}$ of dried leaf powder of Ocimum sanctum. The alphabets on the error bars indicate significant $(\mathrm{p}<0.05)$ differences in the values of a particular variable after oneway ANOVA and Duncan's multiple range test thereafter. Same alphabets indicate no significant change in the values of a particular variable

effects have been observed from our study. We found that Hexamita infection increases the lipid peroxidation which is considered as a marker of stress and quality of health. On the other hand, we also found that a significant decrease of antioxidative enzymes which support the ill health of fish.

However, after treatment of the dried leaf powder of 0 . sanctum, we found that decrease level of stress marker MDA and a significant increase of the antioxidative enzymes (CAT, SOD, and GPx) which promotes the fish good health. Generation of a large amount of free radicals, especially reactive oxygen species, during the infection of fish causes an elevated oxidative stress. SOD together with GPx and CAT forms the main enzymatic defense system against harmful effects of free radicals. Thus, it is evident that leaf powder of 0 . sanctum by playing the modulating role of an antioxidant may promote to minimize the free radical damage and ultimately lead to improve the quality of health of the infected fish. Finally, the data presented in this study suggest that actions of 0 . sanctum in neutralizing oxidative stress in the liver and accelerate the wound healing in Hexamita-infected fish.

\section{CONCLUSION}

This experiments will show the prophylactic quality of the dried leaf powder of $O$. sanctum to reduce the oxidative stress and recovery from Hexamita infection of fish $A$. testudineus. These fish have a great economic importance in India. This may possibly help the aquaculture industry to control the most mortality creating protozoan Hexamita sp. infection, but further research is required to make it more optimum on this method.

\section{ACKNOWLEDGMENT}

We are thankful to the Department of Zoology, The University of Burdwan, for providing the infrastructural facilities and necessary financial support. 


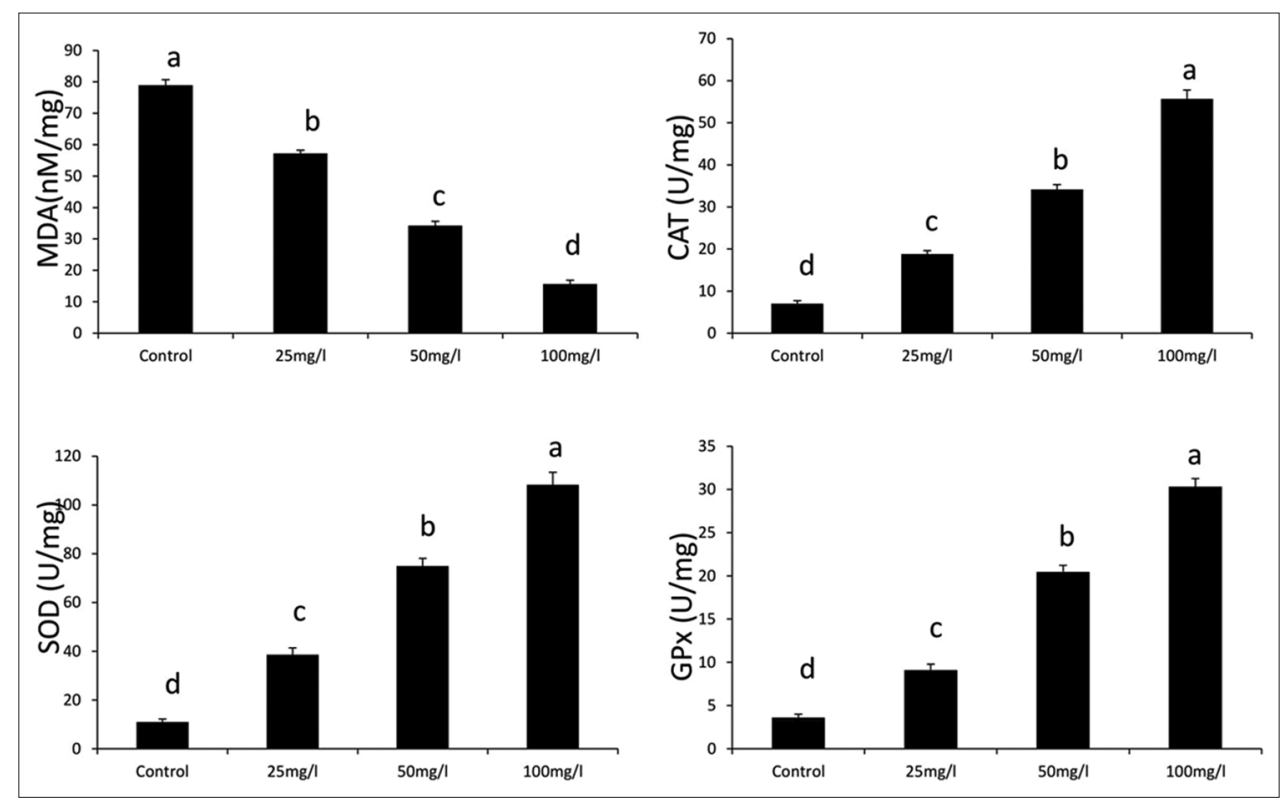

Fig. 5: Diagrammatic presentation of the mean values ( \pm standard error of mean, in vertical bars) of the levels of oxidative stress marker malondialdehyde (MDA) and different enzymatic antioxidant (superoxide dismutase [SOD], catalase [CAT], and glutathione peroxidase [GPX]) in the liver of Anabas testudineus in different experimental group following control, $25 \mathrm{mg} / \mathrm{l}, 50 \mathrm{mg} / \mathrm{l}$, and $100 \mathrm{mg} / \mathrm{l} \mathrm{of} \mathrm{the} \mathrm{dried}$ leaf powder of Ocimum sanctum. The alphabets on the error bars indicate significant $(p<0.05)$ differences in the values of a particular variable after one-way ANOVA and Duncan's multiple range tests thereafter. Same alphabets indicate no significant change in the values of a particular variable. MDA; CAT; GPx; SOD

\section{AUTHORS' CONTRIBUTIONS}

Concept, design of the work, experimental work, and interpretation of data were done by Dr. Pradip Mondal and drafting of the article was done by Dr. Nimai Chandra Saha.

\section{CONFLICTS OF INTEREST}

The authors declare that there are no conflicts of interest.

\section{REFERENCES}

1. Smita K, Manjunathm K, Sarangi S. Evaluation of $\alpha$-glucosidase inhibitory potential of methanolic leaf extract of Ocimum canum. Int $\mathrm{J}$ Pharm Pharm Sci 2017;10:126-31.

2. Joshi B, Sah GP, Basnet BB, Bhatt MR, Sharma D, Subedi K, et al. Photochemical extraction and antimicrobial properties of different medicinal plants: Ocimum sanctum (Tulsi), Eugenia caryophyllata (Clove), Achyranthes bidentata (Datiwan) and Azadirachta indica (Neem). J Microbiol Antimicrob 2011;3:1-7.

3. Nahak G, Sahu RK. Immunostimulatory effect of Ocimum sanctum Linn. Leaf extract in Clarias batrachus Linn. Asian J Pharm Clin Res 2014;7:157-63.

4. Ashok JP, Harish PH, Prasad WV, Ashok WP. Comparative assessment of antioxidant potential of Cassia auriculata (Linn.) flower, leaf and seed methanolic extracts. Int J Pharm Pharm Sci 2015;7:381-5.

5. Jadhav HR, Singh A, Bhutani KK. Rationale for immunomodulatory and anti-inflammatory effects of Ocimum sanctum: Radical scavenging potential and effect on nitric oxide production. Acta Horticulturae 2005;678:159-62.

6. Jeba CR, Vaidyanathan R, Kumar RG. Immunomodulatory activity of aqueous extract of Ocimum sanctum in rat. Int J Pharm Biomed Res 2011;2:33-8.

7. Lom J, Dyková I. Protozoan Parasites of Fishes. New York: Elsevier Science Publishers; 1992.

8. Abowei JF, Briyai OF, Bassey SE. A review of some basic parasite diseases in culture fisheries flagellids, dinoflagellides and ichthyophthriasis, ichtyobodiasis, coccidiosis trichodiniasis, heminthiasis, hirudinea infestation, crustacean parasite and ciliates. $\mathrm{Br}$ J Pharmacol Toxicol 2011;2:213-26.

9. Davis HS. Octomitus salmonis, a parasitic flagellate of trout. Bull Bur Fish 1926;42:9-26.

10. Roberts RJ, Shepherd CJ. Handbook of Trout and Salmon Diseases.
Surrey: Fishing News (Books) Ltd.; 1974.

11. Amlacher E. Die wirkung des malachitegriins auf rische, fisch parasitten (Ichthyophthirius, Trichodina) kleinkrebse und waserpfianzen. Deutsch Fischerei Ztg 1961;8:12-5.

12. Uzmann JR, Paulik GJ, Hayduk SH. Experimental hexamitiasis in juvenile coho salmon (Oncorhynchus kisutch) and steel head trout (Salmo gairdneri). Trans Am Fish Soc 1965;94:53-61.

13. Woo PTK, Poynton SL. Diplomonadida, Kinetoplastida and Amoebida (Phylum Sarcomastigophora). In: Woo PT, editor. Fish Diseases and Disorders. Volume 1: Protozoan and Metazoan Infections. Wallingford: CAB International; 1995. p. 27-96.

14. Gratzek JB. Parasites associated with ornamental fish. Vet Clin North Am 1988;18:375-99.

15. Woo PT. Flagellate parasites of fish. In: Parasitic Protozoa. $2^{\text {nd }}$ ed., Vol. 8. San Diego: Academic Press; 1994. p. 1-80.

16. Naich M, Bilgees FM. Effect of Hexarnita salmonis Moore (1922) on the length and weight of Salmo gairdneri (Richardson). Proc Parasitol 1992;13:23e8.

17. Ferguson HW. Scanning and transmission electron microscopical observations on Hexamita salmonis (Moore, 1922) related to mortalities in rainbow trout fry Salmo gairdneri Richardson. J Fish Dis 1979;2:57-67.

18. Sampaio FG, Boijink CL, Oba ET, dos Santos LR, Kalinin AL, Rantin FT, et al. Antioxidant defenses and biochemical changes in pacu (Piaractus mesopotamicus) in response to single and combined copper and hypoxia exposure. Comp Biochem Physiol C Toxicol Pharmacol 2008;147:43-51.

19. Portaluppi F, Smolensky MH, Touitou Y. Ethics and methods for biological rhythm research on animals and human beings. Chronobiol Int 2010;27:1911-29.

20. Khalil WK, Mahmoud MA, Zahran MM, Mahrous KF. A sub-acute study of metronidazole toxicity assessed in Egyptian Tilapia zillii. J Appl Toxicol 2007;27:380-90.

21. Rusia V, Sood SK. Routine haematological tests. In: Mukerjee KL, editor. Medical Laboratory Technology. New Delhi: Tata McGraw Hill Publishing Company Limited; 1992. p. 252-8.

22. Ewing JF, Janero DR. Microplate superoxide dismutase assay employing a nonenzymatic superoxide generator. Anal Biochem 1995;232:243-8.

23. Aebi H. Catalase in vitro. Methods Enzymol 1984;105:121-6.

24. Castro R, Piazzon MC, Noya M, Leiro JM, Lamas J. Isolation and molecular cloning of a fish myeloperoxidase. Mol Immunol 2008;45:428-37.

25. Draper HH, Hadley M. Malondialdehyde determination as index of 
lipid peroxidation. Methods Enzymol 1990;186:421-31

26. Sano T. Etiology and histopathology of hexamitiasis and an IPN-like disease of rainbow trout. J Tokyo Univ Fish 1970;56:23-30.

27. Yardley JH, Takano J, Hendrix TR. Epithelial and other nsucosst lesions of the jejunurn in gisrdissis. Jejuna biopsystudies. Bull Johns Hopkins Hosp 1964;15:389-406.
28. Molnar K. Data on the" Octomitosis"(spironucleosis) of cyprinids and aquary fishes. Acta Vet Acad Sci Hung 1974;24:99-106.

29. Storey KB. Oxidative stress: Animal adaptations in nature. Braz J Med Biol Res 1996;29:1715-33.

30. Koski KG, Scott ME. Gastrointestinal nematodes, trace elements, and immunity. J Trace Elem Exp Med 2003;16:237-51. 